\title{
The School Library Budget: A Study in Power and Politics of Selected North Carolina School Library Budgets
}

\author{
by Carol Truett and Karen Lowe
}

s local autonomy or site-based management in its purest form grounds for calling a school "naughty"? Some might say so. But does site-based management (SBM) result in power decisions being made by local school teams, or do principals still hold the budget purse strings in most schools? These are but a few of the questions we explored in this study of school library media center budgets in western North Carolina.

Power is defined as the ability to influence or coerce someone, something, or some action. Politics is a power that controls public education. Anyone who does not like politics or power will have a difficult time not only working in education, but in influencing educational outcomes, because they will most likely want to ignore the realities of the educational setting and process. One reality not to be ignored is that school libraries are constantly lacking funds, resulting in a scarcity of new materials year after year.

"Public education in the United States is no longer a democratic process. It has become a bureaucracy, with power centered at the top - in board rooms, administrative offices, and legislative houses. The schoolhouse itself has been muted." 1 Power and politics are key factors in the annual allotment of money to school libraries.

One study found that principals and teachers differ on their views regarding changes in the educational power structures in schools. ${ }^{2}$ Principals perceived their own influence to have increased slightly while teachers believed their influence to have remained the same over the past few years. Principals also perceived teachers to have more influence on school-wide issues than teachers perceived themselves to have. One suspects this is also true for school media specialists. And: "The discrepancies are even greater in regard to school budget, in-service programs, and teacher evaluation. Forty-one percent of the principals - but only $10 \%$ of the teachers - said teachers had a great deal of influence in determining how the school budget should be spent." 3

Michael Strembitsky, Superintendent of the Edmonton, Alberta, public schools for some 22 years instituted school-based management (another name for site-based management or SBM) in 1977. Seven schools were given autonomy in bottom-line budget authority with the money in their buildings. They made all decisions concerning staff, supplies, equipment, and services. They determined the following:

- How much money to spend on supplies, equipment, and services

- How many teachers, custodians, and support staff to be deployed 
They had discretion over $80 \%$ of their resources, versus $2 \%$ for the average school in their district. Stembitsky considered the "experiment" an unqualified success and eventually extended it to the entire district. ${ }^{4}$

Two notable results he mentioned at the experimental stage were as follows:

1) One "NAUGHTY" school dared to buy an IBM Selectric typewriter (when only the Central Office was normally allowed to do so).

2) This same school "saved" enough money to fund and support a fourweek summer reading program with no additional funding from the school district. ${ }^{5}$ This example proves alternate allocation of power, politics, and education to be a successful model where implemented.

One area where budget allocation is often lacking is school library media centers. We see the library media center emerging as the technology hub at an increasing number of schools, but media specialists still face obstacles such as tight budgets, time management problems, and friction with teachers. So what does all of this have to do with school media centers, you might well be saying at this point?

A media center with no budget is like a fish that can't swim. Neither can perform its basic functions, let alone run or swim at optimum performance. In North Carolina, state guidelines developed by the State Department of Public Instruction and published in IMPACT 2000 recommend that $60 \%$ of the per-pupil allotment allocated to each school based on the ADM, or average daily membership or attendance, be used for nonconsumable materials for school library media center.

It appears that media budgets are being diverted to other purposes, especially equipment (technology) and utility bills.

But one suspects that many, if not most, principals have never heard of this recommendation. It appears that media budgets are being diverted to other purposes, especially equipment (technology) and utility bills. And ironically, North Carolina, the home state of Miller and Shontz (who have studied school library media center budgets longitudinally since 1983, and regularly publish the results in School Library Journal), appears to contain pockets of budget ignorance and even deprivation. ${ }^{6}$ In fact, it is strongly suspected that many school libraries may be much worse off than imagined. Miller and Shontz's latest study, incidentally, reported similar findings to the above - technology was increasingly being funded at the expense of books (see their October 2001 Library Journal article cited above, entitled "New Money, Old Books").

This situation is not peculiar to North Carolina. An article in the October 1998 issue of American Libraries was headlined, "Librarians Charge Schools Renege on Book Promise."7 Apparently 30 school media specialists in Orleans Parish, New Orleans, Louisiana, went to a school board meeting complaining that although school board campaign literature stated that money from a school tax was supposed to provide $\$ 23$ per student to purchase library books, only 15 out of 103 schools were using any of the tax money in their libraries. Their current amount of site-based funding ranged from $\$ 0$ per pupil to $\$ 5.61$ per student. And in Portland, Oregon, district spending on library books dropped from $\$ 12.28$ per student in 1991-92 to $\$ 2.13$ in $1996-97.8$

Because of school-based budgeting some media centers have no book budget at all. A major hypothesis of this research is that keeping school staff, and in particular the media specialist, ignorant of such basic information as school budget allocation is a power play on the part of many school administrators, and totally at odds with the philosophy, intent, and underlying premise of site-based or school-based management.

Stimson and Appelbaum state that, "A source of camouflaged power is unpredictability. When principals withhold information that would enable teachers [substitute "media specialists" for "teachers" here] to do their work 


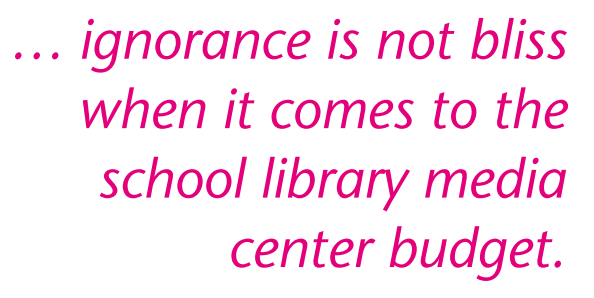

... ignorance is not bliss school library media
center budget. more effectively, they are also using camouflaged power. As the 'gatekeepers' of information flowing from the central office, principals can influence or block decisions by selectively screening information or shutting it off altogether." ${ }^{9}$ Unfortunately ignorance is not bliss when it comes to the school library media center budget.

\section{Rationale and Basis for this Study}

The authors of this study both teach a course called "Management of the School Library Media Center" in the Appalachian State University Master of Library Science degree program. A major topic studied in this course is the school library budget and the budget process. One of the authors has fifteen years experience in working with media specialists not only in the study locale but across North Carolina and in other states as well. Several years ago it became apparent to the authors that many of our students, a large percentage of whom were already practicing school media specialists, either had no budget at all allocated to the library, or they had a very small allocation, and what they did have was doled out on an irregular and frequently somewhat erratic, if not downright whimsical, basis.

Presently state funding provided to North Carolina public schools is based on a figure called average daily membership (ADM), a figure calculated according to a formula based on student enrollments in each school. When this enrollment figure is established, the state education budget for each school is figured simply by multiplying this enrollment number by the per-child allocation determined by the state. Furthermore, the "suggested" allocation to the school media center is $60 \%$ of the instructional materials budget, which for the school year 2001-2002 was set at $\$ 48.30$ per pupil. Sixty percent of this would be two cents short of $\$ 29.00$ per student.

It became evident that this formula was not being used when many of our students complained of little or no monies. When so many of them stated that they basically had no library budget, we began to suspect that some "interesting" things were going on in individual schools, and that this was happening regardless of whether there was a district media coordinator. We developed a number of hypotheses that we wanted to test by administering a simple survey to selected school districts in our catchment service area. While the majority of our respondents came from five large county school districts, there were several other districts whose employees provided survey responses as well. To preserve the confidentiality of these respondents and their districts, and in appreciation for their participation in the study, we will not name them. But suffice it to say that all are located in western North Carolina. In general, the study attempted to determine to what extent school districts empower local schools through site-based management teams, how principals use the school budget as a power tool for control, and how these factors affect school library media specialists in terms of the budgets for their library programs.

Our major hypotheses were as follows:

1. a) Many North Carolina school media specialists are kept in ignorance of the school's budget and their own library budget. This principle is in direct contradiction to site-based management, where all stakeholders know the school's resources and share in the important allocation of resources. b) Or, at the very least, the site-based management team makes important budget decisions.

2. a) Many principals are maintaining a tight control on the budget purse strings. For them, this is a power play which effectively negates empowering the site-based management or school improvement team (SIT). b) Keeping everyone, and especially the media specialist, igno- 
rant of the total budget available also effectively keeps the principal in control.

3. Some site-based management teams or SITs have little real power to allocate resources in their schools.

4. Site-based management is not the school media specialist's best friend. In other words, we wanted to compare those school library budgets where there was a site-based management team or SIT with those who had no such group, as well as compare the budgets of school libraries where the media specialist sat on the committee with those where s/he did not have membership on it.

There were 81 respondents to the survey, and while this is certainly not a sufficient number to generalize the results on a nationwide basis, we feel that it was adequate for our purposes and to establish some budget patterns for Western North Carolina. Let us examine the results in detail.

It is very revealing to see the responses to the question, Does your school have a site-based management or a school improvement team? We made no distinction between the two, although if one really thinks about it, there is a world of difference in the two conceptually. In fact, the SIT is apparently the response of North Carolina's public schools to the mandate that all schools would have site-based management (SBM). As shown in Table 1, only 5 schools said they had no such committee.

Table 1:

\begin{tabular}{|c|c|c|}
\hline \multicolumn{3}{|c|}{ Does your school have a site-based management team? } \\
\hline Response & Frequency & Percent \\
\hline No & 5 & 6.2 \\
Yes & 76 & 93.8 \\
Total & 81 & 100.0 \\
\hline
\end{tabular}

Over 90\% (93.8\%) reported that they had this committee or team in their schools. But as Table 2 clearly shows, two-thirds (66.7\%) of the media specialists who responded were not on this team or committee. Further, when it came to determining or reporting what this group did, Table 3 shows that a quarter $(25.6 \%)$ of those reporting said that this team did not make the important resource allocation decisions or curriculum decisions.

Table 2:

\begin{tabular}{|c|c|r|c|}
\hline \multicolumn{4}{|c|}{ Are you on your school's improvement or site-based } \\
management team? \\
\hline Response & Frequency & Percent & Cumulative Percent \\
\hline No & 54 & 66.7 & 66.7 \\
Yes & 27 & 33.3 & 100.0 \\
Total & 81 & 100.0 & \\
\hline
\end{tabular}

Table 3:

Does this team make fiscal decisions about the allocation of discretionary personnel, the emphases for educational programs (i.e., major curriculum decisions), and/or the budget allocations for the school?

\begin{tabular}{|c|c|c|c|c|}
\hline Response & Frequency & Percent & Valid Percent & Cumulative Percent \\
\hline No & 20 & 24.7 & 25.6 & 25.6 \\
Yes & 29 & 35.8 & 37.2 & 62.8 \\
Only some & 29 & 35.8 & 37.2 & 100.0 \\
Total & 78 & 96.3 & 100.0 & \\
Missing & 3 & 3.7 & & \\
Total & 81 & 100.0 & & \\
\hline
\end{tabular}


Only a third reported that their team made all three of these important decisions, and another third said they made only some of these decisions.

Table 4 indicates that while almost two-thirds of the respondents (64.2\%) did know that there was a correlation between student enrollment and the school's budget, almost another third (29.6\%) did not know or at least could not articulate this fact. Table 5 summarizes the responses to how the library media center money was allocated at the school level. While "by enrollment" was the highest response, with slightly over one-third (35.8\%) reporting this, almost $15 \%$ reported the principal made the decision, while $16.2 \%$ simply didn't know. Almost 5\% of respondents said no monies were specific to the media center. A very small percentage reported that the SIT or SBM team made the decision. Ironically, many of these answers do not make sense because the question asked was how is library money allocated to each school, not within the school. Additional questions regarding this allocation were asked later in the survey.

Table 4:

Briefly, how is money allocated in your school district among schools?

\begin{tabular}{|l|c|c|c|}
\hline Response & Frequency & Percent & Cumulative Percent \\
\hline County decides & 5 & 6.2 & 6.2 \\
ADM/enrollment & 52 & 64.2 & 70.4 \\
Don't Know & 24 & 29.6 & 100.0 \\
Total & 81 & 100.0 & \\
\hline
\end{tabular}

Table 5:

\begin{tabular}{|l|c|r|c|}
\hline \multicolumn{4}{|c|}{ How is the library media center money allocated to each school? } \\
\hline Response & Frequency & Percent & Cumulative Percent \\
\hline SIT or SBM Team & 10 & 12.3 & 13.5 \\
Principal & 12 & 14.8 & 29.7 \\
ADM/enrollment & 29 & 35.8 & 68.9 \\
None specific to LMC & 4 & 4.9 & 74.3 \\
By Site & 7 & 8.6 & 83.8 \\
Don't Know or & 19 & 16.2 & 100.0 \\
No Response & 81 & 100.0 & \\
Total & & & \\
\hline
\end{tabular}

When asked about their book allocations for the library (Table 6), over one-third (37.0\%) indicated by omission that they had no book budget, while another $7.4 \%$ reported a flat-out $\$ 0$. If we combine these two figures (i.e., 30

Table 6:

\begin{tabular}{|r|c|c|c|c|}
\hline \multicolumn{5}{|c|}{ Library budget allocation for the book collection } \\
\hline \multicolumn{1}{|c|}{ Response } & Frequency & Percent & Valid Percent & Cumulative Percent \\
$\$ 50$ & 6 & 7.4 & 11.8 & 7.4 \\
$\$ 500-\$ 1,500$ & 3 & 3.7 & 5.9 & 11.1 \\
$\$ 1,600-2,000$ & 7 & 8.6 & 13.7 & 19.7 \\
$\$ 2,500-\$ 3,500$ & 11 & 13.6 & 21.6 & 33.3 \\
& & & & $53 \%$ \\
$\$ 4,000-\$ 5,000$ & 8 & 9.9 & 15.7 & 43.2 \\
$\$ 5,400-\$ 6,500$ & 8 & 9.9 & 15.7 & 53.1 \\
$\$ 7,000-\$ 8,000$ & 6 & 7.4 & 11.8 & 60.5 \\
$\$ 9,000$ or over & 2 & 2.5 & 3.9 & 100.0 \\
& & & & \\
\hline Total Respondents & 51 & 63.0 & & \\
Missing & 30 & 37.0 & & \\
Total & 81 & 100.0 & & \\
\hline
\end{tabular}


plus 6 ), we see that almost $45 \%$ had no book budgets according to their responses.

A further study of Table 6 indicates that $53 \%$ of those actually reporting a budget figure had $\$ 3,500$ or less to spend on books. Assuming that the average enrollment of these schools was 250 pupils (a purely hypothetical and purposely low figure since we did not ask for enrollment data), even at $\$ 3,500$ for the "typical" book budget, this would amount to only $\$ 14$ per student, hardly enough at today's book prices to purchase one book per student.

Budget allocations for various other media formats and equipment appeared to be so rare (i.e., most did not report having an allocation) that this data was simply combined in Table 7 , which indicates whether or not a media specialist reported any monies for that budget category. However, an actual dollar amount of $\$ 0$ is reported in the table as no budget allocation for the category.

Table 7:

\begin{tabular}{|l|c|c|}
\hline \multicolumn{4}{|c|}{ Budget Allocations for Selected Library Categories } \\
\hline Budget Category & Responses & Percent \\
\hline \multirow{2}{*}{ Book collection } & No 36 & 44.4 \\
& Yes 45 & 55.6 \\
\hline Computer software & No 62 & 76.5 \\
(includes CD-ROMs) & Yes 19 & 23.5 \\
\hline Other software (videos, & No 68 & 84.0 \\
laser disks, etc.) & Yes 13 & 16.0 \\
\hline Internet access (in the & No 76 & 93.8 \\
media center) & Yes & 6.2 \\
\hline \multirow{2}{*}{ Magazines/periodicals } & No 39 & 48.2 \\
& Yes 42 & 51.8 \\
\hline \multirow{2}{*}{ Supplies } & No 61 & 75.3 \\
& Yes 20 & 24.7 \\
\hline \multirow{2}{*}{ Equipment } & No 66 & 81.5 \\
& Yes 15 & 18.5 \\
\hline Other expenses (e.g., & No 72 & 88.9 \\
travel, dues, substitutes) & Yes & 11.1 \\
\hline
\end{tabular}

One caution here is that a number of media specialists did report or indicate that they got their funds for some categories on a school-wide basis from technology monies, e.g., their Internet access was part of the schoolwide budget. Note that we have inserted the category of book collection first in this table even though we have included that as a separate table above (Table 6). The intent here was to show that there were only two budget categories for which over half of the respondents indicated they had an allocation. This was, of course, books and periodicals. The only other categories for which nearly one-fourth of the media specialists had allocations were computer software (23.5\%) and supplies (24.7\%).

Reported amounts for other budget categories were minimal. Now it is possible that software was totally networked and the library did not need a separate budget, but how can a library be run with no supply budget? Many of the supplies needed to run a media center are highly library-specific and cannot simply be pulled off the shelves of a central supply storeroom. The point here is clear. Media specialists are not being given monies to fund even the most basic items needed to run their media centers efficiently, let alone 
effectively.

Several questions were designed to determine the media specialists' knowledge of budget processes. For example, one question already examined and summarized in Table 4 indicated that although most of the media specialists realized there was a relationship between enrollment and money allocations, over one-third (35.8\% combining the first and third categories) either didn't know (almost three-tenths) or felt the district pretty much decided the issue. Another question specifically asked about the relationship between ADM and school budgets. Responses to this question indicated that, despite their earlier responses where over 64\% said ADM figures were used to allocate budget monies, the media specialists were really not at all clear about this formula. Two-fifths (44.4\%) said they were not aware of this relationship.

Further evidence of ignorance about budget is indicated by the next three questions (Tables 8,9 , and 10) which inquired about the media specialist's overall budget knowledge and the portion of the school's total which he/she received for the media center's budget. Interestingly, over one-fourth (22 people or $27.2 \%$ ) of the respondents claimed to know the budget total for the entire school as shown in Table 8. Conversely, and more significantly, almost three-fourths $(72.8 \%)$ did not know this information. Only three people, however, reported knowing the amount of the budget that the media center receives (Table 9), an assertion that is inconsistent with the budget amounts reported in the table summarizing total reported budget amounts (Table 11). It would be impossible for the media specialists to report the data used to create the latter table if they did indeed not know the information of which they claimed ignorance. Also, from Table 10, we can see that despite this claim of ignorance, many of the media specialists at least tried to estimate the total percentage of the school budget that they received. Eleven media specialists (13.6\%) attempted to do so, although one did claim to receive $0 \%$.

Table 8:

\begin{tabular}{|ccc|}
\hline \multicolumn{3}{|c|}{ Do you know the budget total for the entire school, excluding salaries? } \\
\hline Response & Number & Percent \\
\hline No & 59 & 72.8 \\
Yes & 22 & 27.2 \\
Totals & 81 & 100.0 \\
\hline
\end{tabular}

Table 9:

\begin{tabular}{|lcc|}
\hline \multicolumn{3}{|c|}{ Do you know the amount of the budget the media center receives? } \\
\hline Response & Number & Cumulative Percent \\
\hline Don't know & 65 & 80.2 \\
No response & 13 & 16.0 \\
Knew & 3 & 3.7 \\
Total & 81 & 100.0 \\
\hline
\end{tabular}

Table 10:

\begin{tabular}{|l|r|r|r|r|}
\hline \multicolumn{5}{|c|}{$\begin{array}{r}\text { What is the percentage of the total school budget that the } \\
\text { media center receives? }\end{array}$} \\
\hline Response & Number & Percent & Cum. \% & Valid \% \\
\hline No \% given & 70 & 86.4 & 86.4 & - \\
Zero \% & 1 & 1.2 & 87.6 & 9.1 \\
$5-7 \%$ & 2 & 2.5 & 90.1 & 18.2 \\
$10-15 \%$ & 3 & 3.7 & 93.8 & 27.3 \\
$30-40 \%$ & 3 & 3.7 & 97.5 & 27.3 \\
$60 \%$ & 1 & 1.2 & 98.7 & 9.1 \\
$75 \%$ & 1 & 1.2 & 100.0 & 9.1 \\
Total & 81 & 100.0 & -13.6 & 100.0 \\
Total est. \% & 11 & - & & \\
\hline
\end{tabular}


Of those reporting, only 5 (adding the last 3 table categories) believed they received $30 \%$ or more of the total school budget.

Another interesting question asked how instructional materials per se were distinguished from library materials and equipment. Almost 15\% reported library materials or equipment were cataloged and/or barcoded; that housing, or where the materials were kept, was a factor (over 10\%); or that budget lines or accounts determined which materials were which (almost 30\%). Only five respondents said no distinction was made.

Table 11:

\begin{tabular}{|r|c|c|c|c|}
\hline \multicolumn{5}{|c|}{ Total Budget Allocation } \\
\hline Response & Number & Percent & Valid Percent & Cumulative Percent \\
$\$ 0$ & 3 & 3.7 & 4.9 & 4.9 \\
$\$ 500-\$ 2,500$ & 9 & 11.1 & 14.8 & 19.7 \\
$\$ 2,501-\$ 5,000$ & 9 & 11.1 & 14.8 & 34.4 \\
$\$ 5,001-\$ 7,500$ & 11 & 13.6 & 18.0 & 52.5 \\
$\$ 7,501-\$ 10,000$ & 10 & 12.3 & 16.4 & 68.9 \\
$\$ 10,001-\$ 15,000$ & 7 & 8.6 & 11.5 & 80.3 \\
Over $\$ 15,000$ & 12 & 14.8 & 19.7 & 100.0 \\
Total & 61 & 75.3 & 100.0 & \\
Missing & 20 & 24.7 & & \\
Total & 81 & 100.0 & & \\
\hline
\end{tabular}

At this time, it is appropriate to focus more closely on Table 11, indicating the total budget allocations reported by the media specialists in our study. The table data was calculated by adding the amounts reported for the various eight budget categories which are listed in Table 7.

Fully three-fourths of the respondents to our survey provided enough data to create this chart. Of those reporting amounts, less than 5\% said they had a budget of $\$ 0$. Almost 30\% reported a budget of either $\$ 500-2,000$ or $\$ 2,501-5,000$. Over half $(52.5 \%)$ had $\$ 7,500$ or less for their library budgets. However, almost one-fifth of those with a budget reported that it was over $\$ 15,000$. In this latter group, the five highest figures reported were $\$ 27,140$; $\$ 31,900 ; \$ 32,400 ; \$ 40,000$; and $\$ 50,800$.

The mean or average for the total budget figure was $\$ 10,155.75$; the range, however, was from $\$ 0$ to $\$ 50,800$, with a median of $\$ 7,450$. It would appear that for school library media centers, at least within our study group, it was either feast or famine.

\section{Types of Budgets Used and Budget Process}

The media specialists were asked to report the type of budget they were using. Only 6 media specialists, or $7.8 \%$ of the total, said they had a formula budget, despite the fact that ADM is a type of formula, i.e., so much money per student (see Table 4). Over two-fifths (43.6\%) said they had a line item/object of expenditure budget, which would appear at first to contradict Table 4, but which, in fact, is often the case since once the formula (ADM) is established, the monies go into school budgets by being placed into a line item. Thus there is overlap here in the type of budgets being used; they are not mutually exclusive. In regard to formulas used, one question asked respondents if they felt the formulas used made sense. While only 39 media specialists responded to this question, 54\% said the formulas made no sense to them; ironically only six mentioned using a formula type of budget. Eighty-five percent of the media specialists (69) responded to a question asking what type of budget process was followed in the past two years. The most revealing response, which came from almost one-third of the media specialists (32.1\%), was that the principal had the final say. Slightly more than $12 \%$ said that some budget process other than those listed in the survey was used, or they did not re- 
spond (almost 15\%), indicating they did not know. One actually stated that she "didn't know." Another group (almost 15\%) stated that they turned in requests; almost $20 \%$ reported submitting a request to the SIT or SBM team. Others stated several other processes were used.

One of the survey questions further explored the budget process by asking the media specialists more specifically how they were involved in this budget process. Their responses are summarized in Table 12. Less than onefifth $(18.5 \%)$ of all survey respondents stated they were on SITs. Of those who responded to the question, over one-third (34.3\% cumulative, combining the first two categories) turned in requests. However, twelve of the respondents claimed they had no involvement. But eight did state they ordered all items (for the school). Of course ordering materials and having a say in what is ordered or selected can be two entirely different matters. Six said they simply spent funds, presumably handed down from "above." It does appear, then, that many are at least minimally involved in the budget process.

Table 12:

\begin{tabular}{|l|r|r|c|c|}
\hline \multicolumn{5}{|c|}{ How the media specialist is involved in the budget process } \\
\hline \multicolumn{1}{|c|}{ Response } & Number & Percent & Valid Percent & Cumulative Percent \\
\hline Submit request & & & & \\
to SIT/SBM Team & 5 & 6.2 & 7.1 & 7.1 \\
Turns in requests & 19 & 23.5 & 27.1 & 34.3 \\
Other involvement & 5 & 6.2 & 7.1 & 41.4 \\
Spends funds & 6 & 7.4 & 8.6 & 50.0 \\
No involvement & 12 & 14.8 & 17.1 & 67.1 \\
On SIT & 15 & 18.5 & 21.4 & 88.6 \\
LMS orders & & & & 100.0 \\
ALL items & 8 & 9.9 & 11.4 & \\
Total & 70 & 86.4 & 100.0 & \\
Missing & 11 & 13.6 & & \\
Total & 81 & & 100.0 & \\
\hline
\end{tabular}

Tables 13 and 14 probably reveal most clearly who holds the budget power or purse strings in the schools surveyed. Media specialists may submit their requests to the SITs or SBM teams, but Table 15 clearly shows that the principal has the final say in budget decisions in almost $80 \%$ of the schools surveyed.

Table 13:

\begin{tabular}{|l|c|c|c|c|}
\hline \multicolumn{5}{|c|}{ Who makes the final budget decisions in the school? } \\
\hline \multicolumn{1}{|c|}{ Response } & Number & Percent & Valid Percent & Cumulative Percent \\
\hline Principal & 63 & 77.8 & 78.8 & 78.8 \\
SBM Team & 9 & 11.1 & 11.3 & 90.0 \\
SIT & 4 & 4.9 & 5.0 & 95.0 \\
Other & 4 & 4.9 & 5.0 & 100.0 \\
Total & 80 & 98.8 & & \\
Missing & 1 & 1.2 & & \\
Total & 81 & 100.0 & & \\
\hline
\end{tabular}

Table 14 further confirms the principal's control over budget matters; in $92.6 \%$ of the cases here, the principal had final approval over budget expenditures. In other words, even though the budget expenditure may have been approved earlier, the principal could veto it at the last minute. And even if he or she didn't make the original decision, the principal could approve or 
reject any expenditure at this point in the budget process. This would appear to confirm one of our major hypotheses - that principals hold the power and control over budget decisions, despite the fact that SITs and SBM teams are virtually universal phenomena, with almost $94 \%$ of those surveyed reporting having such a team in their school. It also lends some strength to our third hypothesis, which was that these teams often have little real power, although one could argue that controlling the money is only one of the power issues in a school setting.

Table 14:

\begin{tabular}{|l|c|c|c|}
\hline \multicolumn{4}{|c|}{$\begin{array}{c}\text { Who has to approve all expenditures before they are sent to the } \\
\text { central office, vendors, or companies? }\end{array}$} \\
\hline Response & Number & Percent & Cumulative Percent \\
\hline Other & 1 & 1.2 & 1.2 \\
School secretary & & & \\
or bookkeeper & 3 & 3.7 & 4.9 \\
Principal & 75 & 92.6 & 97.5 \\
SIT or SBM Team & 2 & 2.5 & 100.0 \\
Total & 81 & 100.0 & \\
\hline
\end{tabular}

Sadly, the majority of school media specialists appeared to see no problems with the budget process they reported. Over three-fourths of those responding to the question of whether they saw any problems with the budget process they had outlined said "no," there were no problems with the process. However, almost one-fourth (23\%) did see some problems with it. Their comments here tell us more than the simple checking of a yes/no answer.

"No say in anything...power monger."

"Technology Committee may create Tech plan to spend funds. Principal may not approve."

"Need a budget."

"Not fully aware of need."

"Principal spends beyond budget. Secretary is aware but feels it's out of her hands."

"It is hard to catch her sometimes...I don't always ask for approval-tell her what I need."

"No open discussions about needs; principal has complete discretion."

"He supports our program (sort of). Only the fact that we don't get 60\% of any budget!"

"In some schools the principal will not allow expenditures even if there is budgeted $\$ \$ . "$

"Redundancy of purchases, not enough informed purchase decisions."

But most merely accepted the status quo. It is unfortunate that more media specialists do not see themselves as change agents or at least employees who should question the "way things are done." Perhaps they feel an obligation to be a team player, so they think that it is all right to have the principal make all the budget decisions.

Fairness or equity issues within the district did not, likewise, appear to concern the study group adversely. Over two-thirds of the media specialists did not know the budget of at least two other media specialists in their district. Only slightly more than half $(54.3 \%)$ of the media specialists responded to the question that asked whether they thought their budget was fair in comparison to others. Over half (52.3\%) of the respondents thought theirs was not fair. But, conversely, almost half $(47.7 \%)$ thought theirs was fair.

One set of questions dealt with the role of district media supervisor. Ninety percent of respondents to this question reported having such a person 
and/or position in their school district, but less than two-thirds said this person was employed full-time to supervise school library duties or coordinate school library media center activities. Fewer than half $(47.2 \%)$ of the respondents indicated this person had a library science degree. The media specialists were asked about the number of years of experi-

It is unfortunate that more media specialists do not see themselves as change agents or at least employees who should question the "way things are done." ence of their district media supervisors. Two-thirds (67.9\%) had five or more years of experience and over half (53.1\%) had ten or more years experience in this district position. This lengthy experience is not at all surprising given that most of them were probably tenured in their districts prior to obtaining the supervisory position.

A final set of questions asked the media specialists why the school media specialist should be informed about budget decisions. What were the benefits, both real and potential, to them of having knowledge about this process? Table 15 summarizes the responses related to this set of questions. It is apparent from the rank-ordered responses that the media specialists realized the importance of their participation in, and knowledge of, the budget process. All of the reasons given for being knowledgeable about the budget were cited by well over half of the survey respondents, and in some cases as many as $80-90 \%$ selected a reason. Only four people gave other reasons for the media specialist having this information. Accountability appeared less important than equity, planning, and student/teacher support issues.

Table 15:

\begin{tabular}{|c|c|c|}
\hline \multicolumn{3}{|c|}{$\begin{array}{c}\text { Reasons that school media specialists should be informed } \\
\text { about the budget process }\end{array}$} \\
\hline Reason & Number & Percent \\
\hline Get a fair share for & & \\
\hline library media center & 73 & 90.1 \\
\hline To plan better & 68 & 84.0 \\
\hline $\begin{array}{l}\text { To assure that monies go } \\
\text { for student learning and } \\
\text { teacher support }\end{array}$ & 58 & 71.6 \\
\hline Accountability & 53 & 65.4 \\
\hline $\begin{array}{l}\text { Ensure that all monies } \\
\text { spent in a timely manner }\end{array}$ & 48 & 59.3 \\
\hline Other reasons & 4 & 4.9 \\
\hline
\end{tabular}

Other reasons included the following:

"The media specialist is often accountable to the county's purchasing agent/bookkeeper for keeping an accurate record of expenditures."

"To insure updated Media Center and curriculum alignment quality resources for students."

"Evaluated on planning for media center."

"Informed decisions."

Finally, the issues of fairness and possible political ramifications of the budget process were directly addressed in the final question which asked, "If you have no budget, or feel yours is not fairly allocated, can you think of any reasons why this is so?" Table 16 shows the responses to this question, and again it would appear that in general school media specialists are not questioning the system. Of course, many did have a budget, and in many cases, a very healthy one was reported; therefore they might be quite satisfied with the amount allocated, or simply happy to have anything. Probably the most significant finding here is that over two-thirds of those who responded to the question stated that they could not think of any reasons, while only one- 
fourth of those who answered the question said yes, they could think of some reasons for inequity. Again, the comments often provide us with more information than the simple checking of a standard response.

Table 16:

\begin{tabular}{|c|c|r|c|c|}
\hline \multicolumn{5}{|c|}{ If you have no budget or you feel that yours is not fairly allocated, } \\
can you think of any reasons why this is so? \\
\hline Response & Number & Percent & Valid Percent & Cumulative Percent \\
\hline No & 48 & 59.3 & 69.6 & 69.6 \\
Yes & 21 & 25.9 & 30.4 & 100.0 \\
Total & 69 & 85.2 & 100.0 & \\
Missing & 12 & 14.8 & & \\
Total & 81 & 100.0 & & \\
\hline
\end{tabular}

Some of the written comments to this final question include the following:

"My school is very old and so are the books. Why don't I get more money than the new schools?"

"We are a new school, still working on budget."

"Principal controls the money."

"Board doesn't support media programs."

"Earlier times, yes. Currently, no."

"Actually we do not discuss budget. I am given a note with $\mathrm{X}$ amount of dollars to spend."

"Money goes to departments, according to testing scores, etc. Math especially."

"Emphasis has been placed on supporting the classroom teachers and their materials. LMC needs to have $\$ \$$ because the LMC supports the entire school."

"There is no democracy in education - only politics."

\section{Summary}

At this point, we will summarize our findings regarding the school media specialists and their budgets in our group studied in Western North Carolina. First, virtually all of them had SBM teams or SITs in their schools; however, only a third of the media specialists were on these teams. There was a great deal of variance in the decisions made by these teams, and a fourth of them made no fiscal decisions.

Two-thirds of respondents did know there was a correlation between ADM (student attendance) and the budget. Over $44 \%$ reported having no book budget and $53 \%$ of those reporting a figure had $\$ 3,500$ or less. Only two budget categories out of eight had budget amounts reported from over half of the media specialists-book collection and magazines. The study group media specialists were for the most part not being given funds for such basics as supplies or equipment.

There was much evidence of general budget ignorance. Inconsistent responses on many questions and the fact that three-fourths did not know the total school budget are two examples. An example of the former is that while $80 \%$ said they did not know the amount the school media center receives, $75 \%$ reported budget figures (as summarized in Table 11). Only five media specialists believed they got $30 \%$ or more of the total school budget. Over half of reporting media specialists had $\$ 7,500$ or less for their total budgets. The mean total budget reported was $\$ 10,156$, but the median was $\$ 7,450$. Less than $5 \%$ of those responding had a budget of $\$ 0$. It appeared to be either feast or famine. Another example of inconsistency is that only six media specialists reported having a formula budget although two-thirds said there was a correlation between ADM and the budget (ADM budgeting is 
formula-based). Moreover, $54 \%$ of respondents said the formulas used made no sense to them.

A wide variety of budget processes were reported. The involvement of the school library media specialist in the budget process was not universal and also varied widely from no involvement, to sitting on the SIT or SBM team, to ordering all items for the school. However, the most common response was that the principal had the final say. Almost $80 \%$ said the principal had the final budget say and over $90 \%$ said he or she had final approval of all expenditures.

Despite all of this, dissatisfaction with the budget process did not appear to be widespread; over $75 \%$ said there were no problems with the budget process. However, when compared with other school media budgets in their district, half thought theirs was fair but, conversely, half thought theirs was not fair.

Ninety percent had a school district media supervisor at the central office level, and two-thirds of these were employed full-time to manage library duties. However, fewer than half of these individuals had a library degree. Planning and student/teacher support were the most important reasons cited for media specialists being informed about budget issues. To a question asking if they could think of any reasons why they had no budget or had one that was not fairly allocated, over one-fourth said yes, they could think of reasons and nine respondents actually supplied comments ranging from "Principal controls the money" to "There is no democracy in education - only politics."

\section{Conclusions}

The hypotheses of the study are stated again below with our conclusions regarding each of them.

Hypothesis 1: a) Many North Carolina school media specialists are kept in ignorance of the school's budget and their own library budget. This is a principle in direct contradiction to site-based management where all stakeholders know the school's resources and share in the important allocation of resources decisions. b) Or, at the very least, the site-based management team makes these important budget decisions.

a) True. Few knew the total school budget and very few knew what percent of this total they received. b) False. In the study group, principals overwhelmingly made the budget decisions, not the SBM teams.

Hypothesis 2: a) Many principals are maintaining a tight control on the budget purse strings. For them, this is a power play which effectively negates empowering the SBM team or SIT. Keeping everyone, and especially the media specialist, ignorant of the total budget available also effectively keeps the principal in control.

a) True. The principals hold the purse strings and frequently keep everyone else ignorant of the total budget situation. Is this a power play or simply sound management practice?

Hypothesis 3: Some SBM teams or SITs have little real power to allocate resources in their schools.

Partly true. Although $94 \%$ have the SBM or SITs teams, only a little over one-third said they made all the budgeting decisions; another one-third said they made only some of these decisions. But this was in direct contradiction to the results of Tables 13 and 14 indicating the principals generally always made both the final budget decisions and the final approval of all purchases.

Hypothesis 4. a) Site-based management is not the school media specialist's best friend. In other words, we wished to compare those school library budgets where there was a SBM team or SIT with those who had no such group. b) A corollary analysis would compare the 
budgets where the media specialist was actually on the team and where they did not have membership on it.

To make these comparisons, we had to create some new tables. Table 17 indicates total budget amounts for those with and without site-based management teams.

Table 17:

\begin{tabular}{|rrr|}
\hline \multicolumn{3}{|c|}{ Does your school have a site-based management team? } \\
\hline Total Budget Allocation & No & Yes \\
$\$ 0$ & & 3 \\
$\$ 1-2,500$ & 1 & 8 \\
$\$ 2,501-5,000$ & 2 & 7 \\
$\$ 5,001-7,500$ & & 11 \\
$\$ 7,501-10,000$ & 1 & 9 \\
$\$ 10,001-15,000$ & & 7 \\
Over $\$ 15,000$ & & 12 \\
\hline
\end{tabular}

a) False. Since virtually all schools had SBM teams or SITs, the data includes too few numbers in the "No" category to make significant statistical comparisons between the two groups; however, the twelve schools whose media centers had the largest budgets did have sitebased management. Therefore we cannot say that SBM teams or SITs are necessarily the media specialist's worst enemy. As an examination of Table 17 clearly shows, many, if not the majority, of the best-funded libraries had these teams. Data from earlier tables, however, indicates the often limited budgetary responsibility of these teams.

b) The media specialist's presence on the team, as indicated in Table 18, did not appear to be the overwhelming influence for the high library budgets which some schools reported. Of those with over $\$ 15,000$, half had a media specialist on the team, but half did not. Indeed, of those reasonably well-funded (i.e., those with over $\$ 7,501$ total budget), only twelve had media specialists on the SBM teams or SITs, while seventeen did not. Two final conclusions may be drawn after studying this data. SBM teams or SITs are neither friend nor foe, necessarily, of the school media specialist; therefore, school media specialists need to start speaking up more as members of these teams to secure better budgets for their libraries!

Table 18:

\begin{tabular}{|rcc|}
\hline \multicolumn{4}{|c|}{ Are you on your school improvement or site-based management team? } \\
\hline Total Budget Allocation & No & Yes \\
$\$ 0$ & 2 & 1 \\
$\$ 1-2,500$ & 7 & 2 \\
$\$ 2,501-5,000$ & 7 & 2 \\
$\$ 5,001-7,500$ & 9 & 2 \\
\hline$\$ 7,501-10,000$ & 8 & 2 \\
$\$ 10,001-15,000$ & 3 & 4 \\
Over $\$ 15,000$ & 6 & 6 \\
\cline { 2 - 3 } Subtotal over $\$ 7,501$ & 17 & 12 \\
\hline
\end{tabular}

We did an additional analysis, comparing the total budgets where there was a district media supervisor and where there was none in place. Table 19 summarizes this data.

Since most had a district media supervisor, meaningful statistical correlations are not possible, but it can readily be seen that those with the highest 
Total Budget Comparisons of Those With and Without District Media Supervisors

\begin{tabular}{|rcr|}
\hline Total Budget Allocation & No & Yes \\
$\$ 0$ & 0 & 3 \\
$\$ 1-2,500$ & 1 & 7 \\
$\$ 2,501-5,000$ & 2 & 7 \\
$\$ 5,001-7,500$ & 1 & 10 \\
\hline$\$ 7,501-10,000$ & 1 & 9 \\
$\$ 10,001-15,000$ & 0 & 7 \\
Over $\$ 15,000$ & 1 & 11 \\
\cline { 2 - 3 } & 2 & 27 \\
\hline
\end{tabular}

total budgets generally always had a district media supervisor. A caution here, of course, is that those with more money in general (i.e., the richest school districts overall) are probably more likely to have both better library budgets and the ability to afford a district media coordinator's salary.

\section{Postscript}

Finally, we admit that some of our suspicions posed as hypotheses were not found to be true. SBM teams or SITs are not necessarily the media specialist's enemy. But we did find that great inequities do exist in terms of school library budget amounts, and that there are indeed media specialists who receive no monies for many, if not all, of the anticipated (and needed) media center budget categories. We do feel, however, that school media specialists should, after thoroughly educating themselves on the total school budget and on their own particular budget needs, continually make a case for increasing the library budget based on what will benefit the total school and its curriculum.

The SBM team or SIT is not the place to keep quiet about the media center's needs, because in the final analysis those needs are everyone's needs. Continual dialogue with both the administration and the faculty about the budget is critical to a healthy library media center, as is a strong public relations program that publicizes how the library meets the needs of students and promotes and fosters student achievement and academic goals. It is obvious that these teams are only one venue for getting or improving library budgets. The principal, still the major power player in the school, must be continually wooed and apprised of the library's budgetary needs.

While some may say it is a stretch to consider the budget a power tool, we feel that in many cases, our perception of this is true. The comments our survey respondents made indicate that they are, for the most part, well aware of the relationship between power and politics in their schools and how it plays out in the budget process.

\section{References}

[Note: The authors are grateful to Karen Rhodes for her assistance with their research and Dr. L. Arthur Safer for his enthusiastic support. Rhodes is a Graduate Research Assistant, and Safer is Chair of the Library and Education Studies Department, Reich College of Education, Appalachian State University.]

${ }^{1}$ Robert M. Ferris, "Real Education in a Real Democracy," Mothering 68 (Fall 1993): 90.

2 Jianping Shen, "Do Teachers Feel Empowered?" Educational Leadership 55 7 (Apr. 1998): 35-36.

3 Ibid., 35.

${ }^{4}$ John O'Neil, “On Tapping the Power of School-Based Management: A 
Conversation with Michael Strembitsky," Educational Leadership 53

(Dec.1995/Jan. 1996): 66-70.

5 Ibid., 67.

6 Marilyn L. Miller and Marilyn L. Shontz, "New Money, Old Books," School Library Journal 47 (Oct. 2001): 50-60.

7 Carol Kristl, "Librarians Charge Schools Renege on Book Promise," American Libraries 29 (Oct. 1998): 16-17.

8 Andrea Glick, "Portland, OR, Bookstore Shares Profits with School Libraries," School Library Journal 44 (Mar. 1998): 97.

9 Terry D. Stimson and Richard P. Appelbaum, "Empowering Teachers: Do Principals Have the Power?" Phi Delta Kappan 70 (Dec. 1988): 313-16.

\section{Selected Bibliography}

Cummins, Julie. "Average Book Prices '01: Dead Trees and Wooden Nickels." School Library Journal 47 (Mar. 1, 2001). <http://slj.reviewsnews.com/ index.asp?layout=articlePrint\& articleID $=C A 153511>$ (Accessed Aug. 29, 2002)

Ferguson, Marilyn. The Aquarian Conspiracy: Personal and Social Transformation in the 1980s. Los Angeles: J.P. Tarcher, 1980.

Ferris, Robert M. "Real Education in a Real Democracy." Mothering 68 (Fall 1993): 90-96.

"Funding and Budgeting for the School Library" in The IFLA/UNESCO School Library Guidelines. 2002. <http://www.ifla.org/VII/s11/pubs/sguide02.pdfs (Accessed Aug. 29, 2002)

Gerhardt, Lillian N. "Average Book Prices '98." School Library Journal 44 (Mar. 1998): 79.

Glick, Andrea. "Portland, OR, Bookstore Shares Profits with School Libraries." School Library Journal 44 (Mar. 1998): 97.

Gonzales, Edwin and Paula M. Short. "The Relationship of Teacher Empowerment and Principal Power Bases." Journal of Instructional Psychology 23 (Sept. 1996): 210-15.

Johnson, Doug. The Indispensable Librarian: Surviving (and Thriving) in School Media Centers. Worthington, OH: Linworth Publishing, 1997.

Klecker, Beverly J., and William E. Loadman. "Defining and Measuring the Dimensions of Teacher Empowerment in Restructuring Public Schools." Education 118 (Spring 1998): 358-70.

Kristl, Carol. "Librarians Charge Schools Renege on Book Promise." American Libraries 29 (Oct. 1998): 16-17.

Lowe, Karen. "Resource Alignment: Providing Curriculum Support in the School Library Media Center." Knowledge Quest 30 (Nov./Dec. 2001): 2732.

Miller, Marilyn L., and Marilyn L. Shontz. "Small Change: Expenditures for Resources in School Library Media Centers, FY 1995-96." School Library Journal 43 (Oct. 1997): 28-37.

—. "How Do You Measure Up?" School Library Journal 45 (Oct. 1999): 5059.

—. "New Money, Old Books." School Library Journal 47 (Oct. 2001): 50-60.

O'Neil, John. "On Tapping the Power of School-Based Management: A Conversation with Michael Strembitsky." Educational Leadership 53 (Dec.1995/Jan. 1996): 66-70.

Patterson, Jerry L., Stewart C. Purkey, and Jackson V. Parker et al. Productive School Systems for a Nonrational World. Alexandria, VA: Association for Supervision and Curriculum Development, 1986.

Peck, M. Scott. The Different Drum: Community-Making and Peace. New York: Simon \& Schuster, 1987. 
"Program Administration; Budgeting for the Program" in Impact: Guidelines for Media and Technology Programs. Raleigh, NC: NCDPI, 2000. $<$ http://www.ncwiseowl.org/impact/program.htm\#Budgeting for the Program $>$ (Accessed Aug. 14, 2002)

"Rider 67 for School Library Materials Deleted from TEA's Preliminary Budget." TLA Texline No. 136: Legislative Issues Network. Texas Library Association, Sept. 26, 2002. <http://www.txla.org/pubs/texline/ 020926B.html $>$ (Accessed Aug. 14, 2002)

"School Library Budget." Philadelphia, Penn.: School District of Philadelphia, Dec. 5, 2001. <http://www.libraries.phila.k12.pa.us/misc/ budget.html> (Accessed Aug. 14, 2002)

Shen, Jianping. "Do Teachers Feel Empowered?" Educational Leadership 55 (Apr. 1998): 35-36.

Stimson, Terry D., and Richard P. Appelbaum. "Empowering Teachers: Do Principals Have the Power?" Phi Delta Kappan 70 (Dec. 1988): 313-16.

Thorsheim, Howard, and Bruce Roberts. "The 'Flavor' of the Social Ecology Paradigm in Use: Building on Mutual Social Support in Preventing Drug Abuse." ERIC document: ED 240427, 1983.

Williams, John C., Kenneth L. Moffett, and Bruce Newlin. "The District Role in School Renewal."In The Ecology of School Renewal. Ed. by John Goodlad. Chicago: National Society for the Study of Education, dist. by University of Chicago Press, 1987. 